\title{
希薄アンモニア水による石炭ガス脱硫法の研究 (I)
}

\author{
一アンモニア水に対する $\mathrm{HCN}, \mathrm{H}_{2} \mathrm{~S}$ および $\mathrm{CO}_{2}$ の溶解平衡一
}

- 1998. 5. 25 受理一

東京ガス株式会社 黒木 正章

\section{1. 緒 言}

COG (コークス炬ガス) はメタン，水素および一酸 化炭素を主成分とする燃料ガスであるが，不純物とし てタール, 軽油, ナフタリンのほか, アンモニア, 硫 化水素㧍よびシアン化水素等の非炭化水素ガスを含有 している。

これらの不純物は装置や配管を閉塞したり腐食する ほか，燃焼すると硫黄酸化物や窒素酸化物等の有害ガ スを排出するため完全に除去する必要があり，なかで も除去が困難な硫化水素に関しては極めて多種類の脱 硫プロセスが開発されてきた。

しかし多くの脱硫プロセスは経済性と技術先進性に 優れたものではあったが, 環境適応性や資源還流(リ サイクル)性等, 現在の社会が最も重視しているコン セプトにとって最適のものとはいえない。このような 観点に基づいた石炭利用技術の開発は，アジアの開発 途上国とりわけ中国などにおける石炭利用の今後の急 増を考慮すれば重要な課題である。

COG 脱硫においてレドックス触媒を使用する湿式 酸化法は, 効率が高くかつ硫化水素を硫黄に固定でき る特徴が評価され，ほとんど全ての COG 脱硫装置に おいてこの方式が採用されてきた。しかし，本法には アルカリ薬液の消耗とそれに付随して発生する高濃度 還元性廃液の処理問題があり，環境への適合性が重視 される現在に於いては大きな課題となっている。こう した観点から, COG の物性が最大限に活用でき, か つ有害反応物か排出しない「アンモニア水洗浄法」に 着目し, 研究をした。

「アンモニア水洗浄法」は過去にも多くの実施 例 $^{1) 2)}$ があるが, 何れの場合も高濃度アンモニア水溶

技術企画部 東京都港区海岸 $1-5-20$
液を使用するため炭酸ガスの吸収が激しく，それに反 して脱硫率は一般に低い。しかも炭酸塩を多量に含ん だ吸収液の再生に多量のスチームを必要とし, 経済性 の面でも問題がある。本研究は比較的多量のアンモ二 アを含有するCOG の物性を考慮し，過去の「アンモ ニア水洗浄法」では見落とされていた希薄アンモニア 水溶液による酸性ガスの吸収法に着目し，その挙動を 化学工学的に検証することを目的とした。

アンモニア水溶液による酸性ガスの吸収に関しては Van Krevelen D.W. ら ${ }^{3)}$ が静的および動的方法で $\mathrm{CO}_{2}$, $\mathrm{H}_{2} \mathrm{~S}$ に関して測定し, また正田ら ${ }^{4) 5)}$ も液柱塔によっ て $\mathrm{CO}_{2}$ 吸収の動的測定をし, 反応吸収理論に基づく 実験式を提案している。

アンモニア水洗浄法による COG 脱硫など化学反応 を伴う吸収においては, 物理吸収との相対的差異を示 す尺度としての反応係数 $\beta$ が重要な意味を有する。し かし反応係数 $\beta$ は反応次数, 反応速度定数, 平衡定数, 液中の各成分の濃度と拡散係数, 液の流動状態などの 諸因子の複雑な関数であって，解析的にその関数形を 求めることは極めて困難である。

本研究では動的実験により求めた溶解平衡係数 (化 学反応を伴うヘンリー定数) $\mathrm{H}$ を反応吸収モデルに組 み入れ, これによって充填塔における吸収性能の評価 手法を検討するため, アンモニア水溶液に対するシア ン化水素の溶解平衡係数を実測した。なお, 硫化水素 および炭酸ガスに関してはV Van Krevelen らが実測し た詳細なデー夕や線図があるため, 本研究ではそれら を活用して溶解平衡係数を算出した。

\section{2. 実験装置および測定方法}

実験装置の概略を Fig. 1 に示す。装置の主要部は 


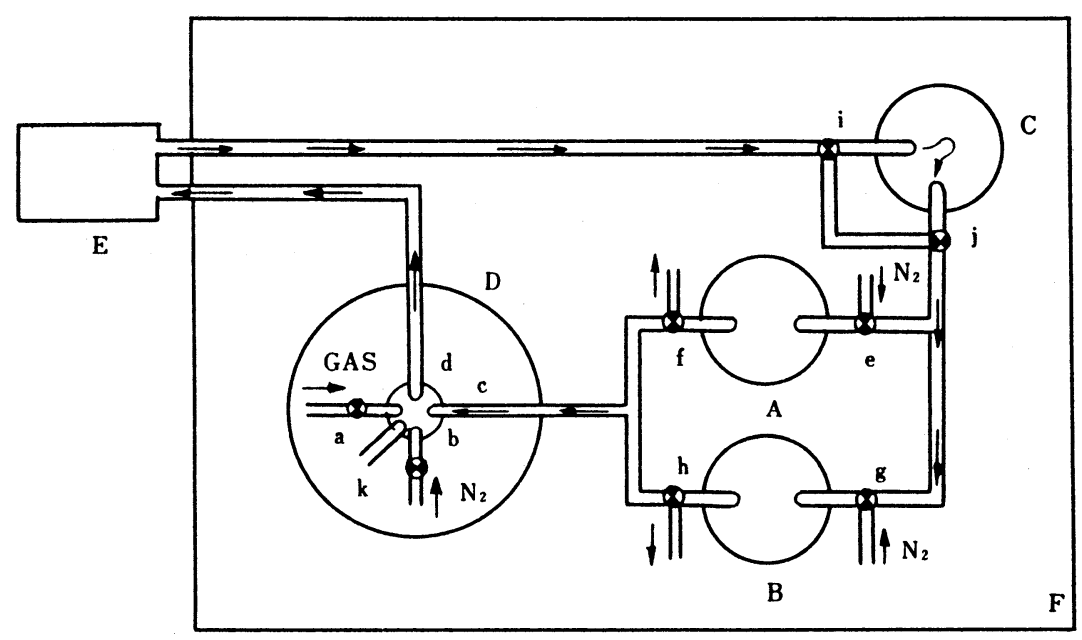

Fig. 1 Schematic diagram of experimental apparatus

A : sampling bottle for initial mixture gas $B$ : sampling bottle for equilibrium gas

$\mathrm{C}$ : absorption device $\mathrm{D}$ : gas holder $\mathrm{E}$ : diaphragm pump $\mathrm{F}$ : water bath

a : HCN inlet $\quad b: N_{2}$ inlet and outlet $\quad c, d$ : circurate inlet and outlet e, g: gas cock for $\mathrm{N}_{2}$

$\mathrm{f}, \mathrm{h}$ : gas cock for sampling absorber $\mathrm{i}, \mathrm{j}$ : by pass cock $\mathrm{k}$ : manometer

恒温水槽に入れ，露出部は赤外線ランプで加温して測 定温度に保った。

実験準備として, 系統全体の真空排気および窒素送 気を数回繰り返し, 吸収瓶 (C)に定量のアンモニア水 溶液を封入した後, 真空ポンプで微少排気しておく。 この状態で予めシリンジに補集しておいたシアン化水 素を試料ガスホルダー (D)に挿入し，系統全体を大気 圧にバランスさせる。吸収試験を実施する前に，吸収 瓶バイパスライン $(\mathrm{i} \sim \mathrm{j})$ を使って約 2 時間攪拌し, 試料ガス補集瓶 $(\mathrm{A})$ を封印する。つぎに吸収瓶のライ ンを活かした状態で 3 時間攪拌し, 平衡ガス補集瓶 (B) と吸収瓶 (C) を平衡状態の気液サンプルとする。

気相サンプルは捕集瓶を $\mathrm{N}_{2}$ パージすることにより， か性ソーダ水溶液を入れた吸収瓶に HCN を捕集して 分析し, 液相サンプルは吸収瓶から直接採取して分析 した。HCN の分析は硝酸銀法 (JIS-K0102)で行ない, 吸收液の全 $\mathrm{NH}_{3}$ 濃度の分析はメチルオレンジを指示 薬とする $\mathrm{HCl}$ 標準溶液滴定法で実施した。得られた 気相成分には飽和水蒸気圧補正を加えた。

実験諸条件は実用を前提とし, 気相 $\mathrm{HCN}$ 初濃度は 平衡時に Table 1 の COG 不純物組成に近づくように 調整し, 温度は $10^{\circ} \mathrm{C}, 25^{\circ} \mathrm{C}, 40^{\circ} \mathrm{C}$ の 3 点とした。また 実験精度を検証するため, 各温度で純水によるシアン 吸収試験を実施し，ヘンリー定数すなわち物理吸収に よる溶解平衡係数 $\mathrm{H}^{*}$ を測定した。
Table 1 Nonhydrocarbon impurities in coal gases

\begin{tabular}{|c|c|}
\hline Type of impurity & Typical concentration \\
\hline Hydrogen sulfide & $4 \sim 10 \mathrm{~g} / \mathrm{Nm}^{3}$ \\
Ammonia & $5 \sim 15 \mathrm{~g} / \mathrm{Nm}^{3}$ \\
Hydrogen cyanide & $1 \sim 2 \mathrm{~g} / \mathrm{Nm}^{3}$ \\
Carbon dioxide & $1.5 \sim 2 \%$ \\
\hline
\end{tabular}

\section{3. 実験結果}

\section{1 シアン化水素のアンモニア水に対する溶解平衡}

実験に先立ち, シアン化水素の純水に対する物理吸 収量を測定し, これから導出される溶解平衡係数を文 献値吕 と比較した結果, Fig. 2 に示すと㧍りよく一致 することが確認された。

$\mathrm{HCN}-\mathrm{NH}_{3}-\mathrm{H}_{2} \mathrm{O}$ 系における $\mathrm{HCN}$ の気液平衡組成お よび溶解平衡係数 $\mathrm{H}$ を測定し, 実験温度別にして Fig. 3 に示した。溶解平衡係数 $\mathrm{H}_{\mathrm{HCN}}$ は平衡状態にお けるシアン化水素の気液比であり，C- $\mathrm{HCN} / \mathrm{L}-\mathrm{HCN}$ から算出した。 $\mathrm{H}_{\mathrm{HCN}}$ は $\mathrm{L}-\mathrm{NH}_{3}$ 濃度とよい相関があり, これを図表解析することにより次式が得られる。

$$
\log \mathrm{H}_{\mathrm{HCN}}=-0.686 \mathrm{x}+0.017 \mathrm{~T}-5.312
$$

ここに, $\mathrm{H}_{\mathrm{HCN}}$ はシアン化水素の溶解平衡係数 $\left(\mathrm{g}-\mathrm{mol} / \mathrm{Nm}^{3} / \mathrm{g}-\mathrm{mol} / \mathrm{l}\right), \quad \mathrm{x}$ はアンモニア濃度 $(\mathrm{g}-\mathrm{mol} / \mathrm{l}), \mathrm{T}$ は絶対温度 $(\mathrm{K})$ である。

本実験では実用の観点から液相アンモニア濃度を 


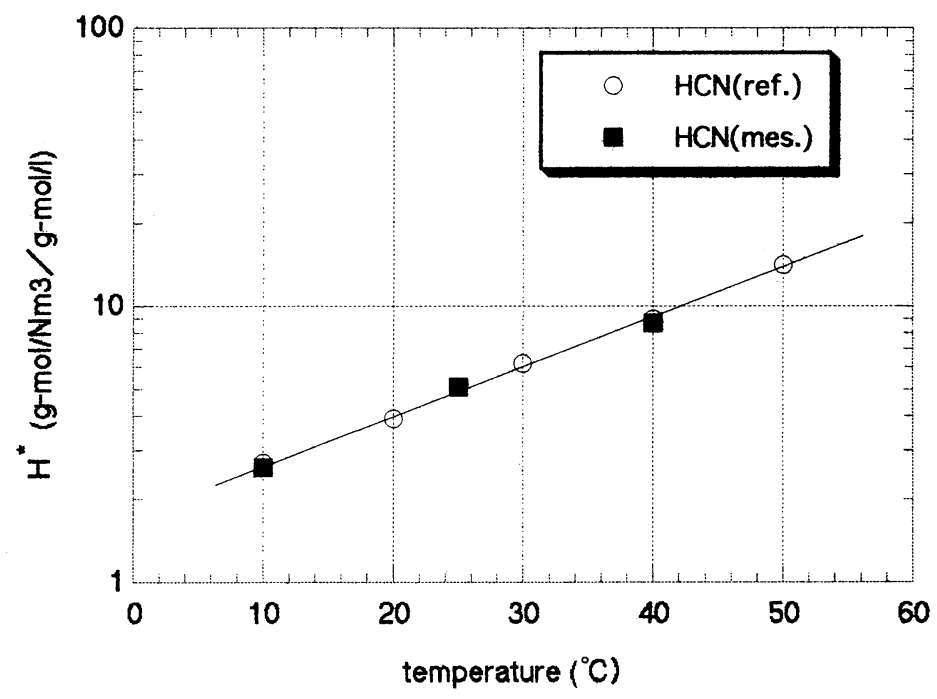

Fig. 2 Henry's law constant of $\mathrm{HCN}$ at the atmospheric pressure

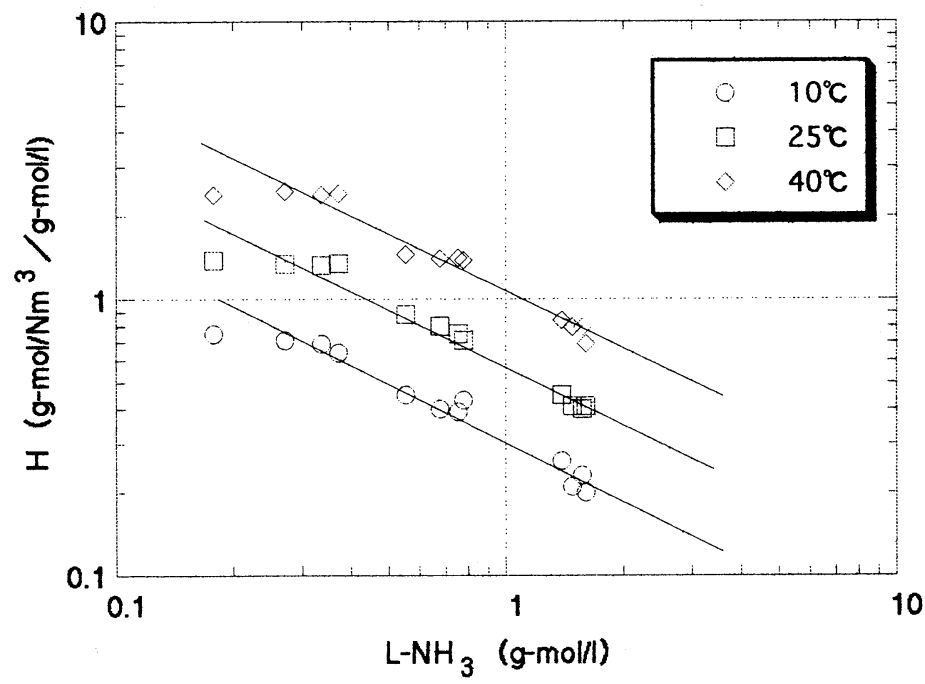

Fig. 3 Henry's law constant of HCN with chemical reaction in ammonia water

$1.5(\mathrm{~g}-\mathrm{mol} / \mathrm{l})$ 以下とし，比較的希薄な領域を主体に測 定したこと，およびシアン化水素のヘンリー定数が小 さいこと，すなわち水に溶解しやすい性状のため，液 相におけるシアン化水素とアンモニアの濃度比 $\mathrm{R} の$ 影響は認められなかった。

\section{2 硫化水素および炭酸ガスのアンモニア水に} 対する溶解平衡係数の算出

硫化水素のアンモニア水に対する溶解平衡係数の導 出に際し, 本研究ではV Van Krevelen らの静的実験
データ を皇活用した。すなわち硫化水素の気相蒸気圧 を濃度換算し，これと液相硫化水素濃度との比をとっ て溶解平衡係数 $\mathrm{H}$ を算出し, 結果の一部を図示した。

Fig. 4, Fig. 5 はそれぞれ温度が $20^{\circ} \mathrm{C}, 40^{\circ} \mathrm{C}$ の場 合で，液相における硫化水素とアンモニアの濃度比 $\mathrm{R}$ $\left(\mathrm{L}-\mathrm{H}_{2} \mathrm{~S} / \mathrm{L}-\mathrm{NH}_{3}\right)$ および温度をパラメータにとると, 硫化水素の溶解平衡係数 $\mathrm{H}$ がアンモニア濃度と極め てよい相関を有することを示している。これを数式化 すると次式が得られる。

$\log \mathrm{H}_{\mathrm{H}_{2} \mathrm{~S}}=-0.036 \mathrm{x}+2.04 \mathrm{R}+0.0272 \mathrm{~T}-9.046$ 


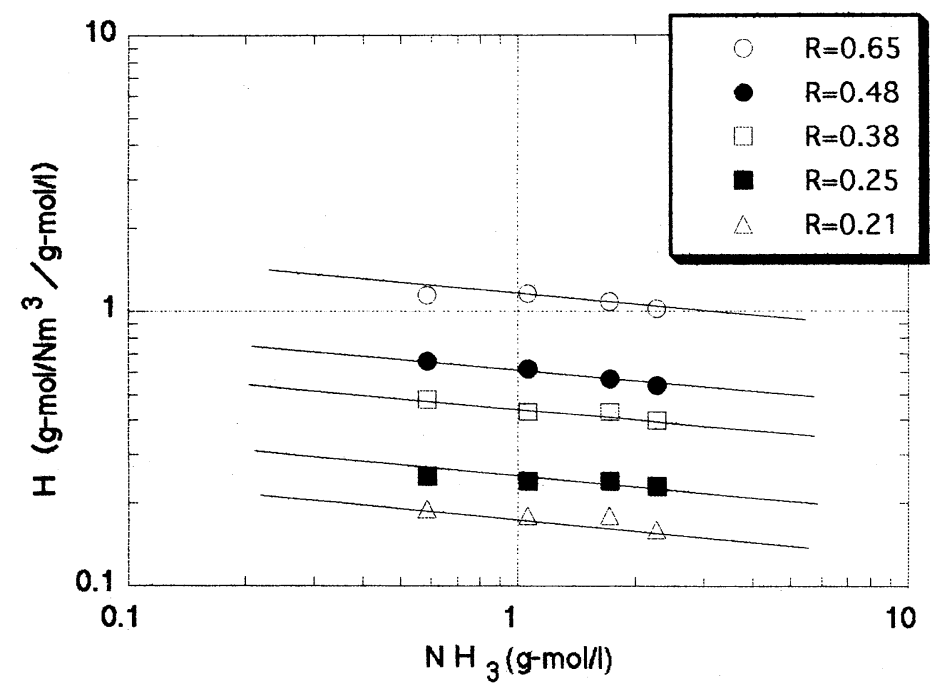

Fig. 4 Henry's law constant of $\mathrm{H}_{2} \mathrm{~S}$ with chemical reaction in ammonia water $\left[20^{\circ} \mathrm{C} 】\right.$ $\mathrm{R}=\mathrm{L}-\mathrm{H}_{2} \mathrm{~S} / \mathrm{L}-\mathrm{NH}_{3}$

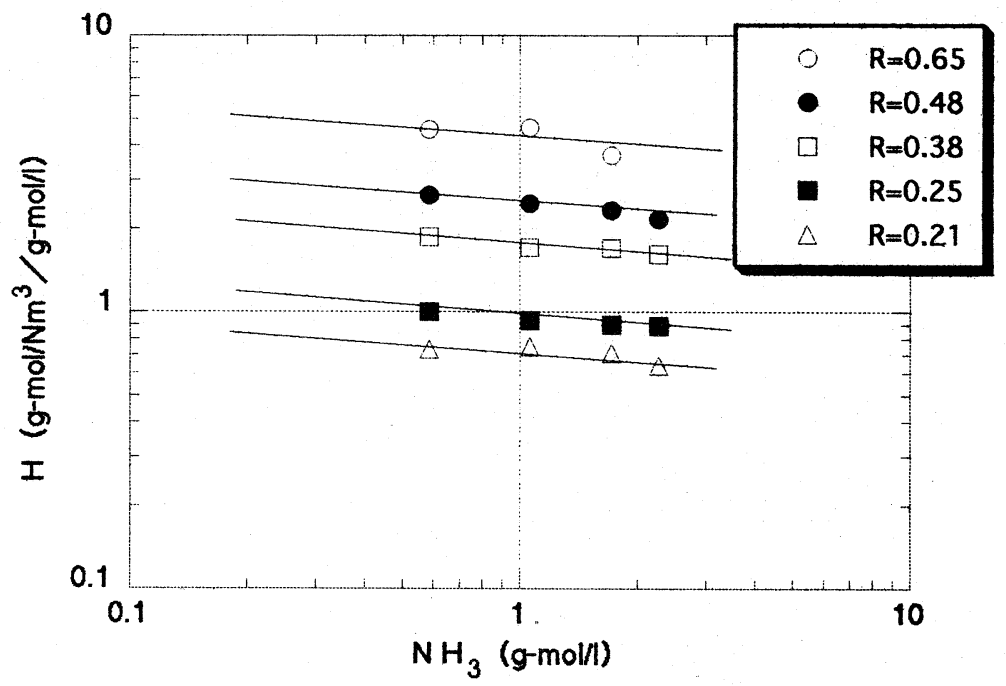

Fig. 5 Henry's law constant of $\mathrm{H}_{2} \mathrm{~S}$ with chemical reaction in ammonia water $\left[40^{\circ} \mathrm{C}\right.$ 】 $\mathrm{R}=\mathrm{L}-\mathrm{H}_{2} \mathrm{~S} / \mathrm{L}-\mathrm{NH}_{3}$

ここに, $\mathrm{H}_{\mathrm{H}_{2} \mathrm{~S}}$ は硫化水素の溶解平衡係数 $(\mathrm{g}-\mathrm{mol} /$ $\left.\mathrm{Nm}^{3} / \mathrm{g}-\mathrm{mol} / \mathrm{l}\right), \mathrm{x}$ はアンモニア濃度 $(\mathrm{g}-\mathrm{mol} / \mathrm{l}), \mathrm{R}$ は 液相の硫化水素とアンモニアの濃度比(一), T は絶対 温度 $(\mathrm{K})$ である。

硫化水素のヘンリー定数はシアン化水素の100倍程 度で, 水には溶解しにくい酸性ガスであるが, J.Knox ら の報告では $\mathrm{pH} 4.0$ $\mathrm{pH} 11.0$ で解離し, $\mathrm{H}_{2} \mathrm{~S} \rightleftarrows \mathrm{H}^{+}$ $+\mathrm{HS}^{-}$の 1 次可逆反応に従う。そのため $\mathrm{R}$ が 0.65 以 下で $\mathrm{H}_{2} \mathrm{~S}$ が副次反応を生じない範囲であれば, 溶解
平衡係数 $\mathrm{H}$ は液相に扔ける硫化水素とアンモニアの 濃度比 $\mathrm{R}$ とよい相関を持っている。

一方, 炭酸ガスのアンモニア水に対する溶解平衡係 数については, Van Krevelen らの静的実験デー夕お よびそれから導出した線図 ${ }^{3)}$ を原始データとした。す なわち線図を数值化し, 気相の炭酸ガス濃度と液相炭 酸ガス濃度との比をとることによって溶解平衡係数を 算出した。

硫化水素の場合と同様の手法で炭酸ガスの溶解平衡 
係数を数式化すると次式が得られる。

$$
\log \mathrm{H}_{\mathrm{CO} 2}=-0.78 \log \mathrm{x}+2.6 \mathrm{R}+0.035 \mathrm{~T}-12.08
$$

ここに, $\mathrm{H}_{\mathrm{CO} 2}$ は炭酸ガスの溶解平衡係数 ( $\mathrm{g}-\mathrm{mol} /$ $\left.\mathrm{Nm}^{3} / \mathrm{g}-\mathrm{mol} / \mathrm{l}\right), \mathrm{x}$ はアンモニア濃度 $(\mathrm{g}-\mathrm{mol} / \mathrm{l}), \mathrm{R}$ は 液相に扮ける炭酸ガスとアンモニアとの濃度比 (一), T は絶対温度 $(\mathrm{K})$ である。

炭酸ガスとアンモニアの反応は複雑で, 炭酸化度が 増すにしたがって気液界面に $\mathrm{NH}_{3}, \mathrm{NH}_{4}{ }^{+}, \mathrm{NH}_{2} \mathrm{COO}^{-}$， $\mathrm{HCO}_{3}{ }^{-}, \mathrm{CO}_{3}{ }^{--}$等の反応生成物が存在するようになる。 そのため液相中の炭酸ガス濃度が高まり $\mathrm{R}$ が大きく なるにしたがって溶解平衡係数 $\mathrm{H}$ は偏奇する。

従って (3) 式は $\mathrm{R}$ が0.4以下でアンモニア濃度が 1 ( $\mathrm{g}-\mathrm{mol} / \mathrm{l})$ 以下の比較的希薄な領域への適用が妥当と 考えられるが，COG 精製の検討に供する領域におい ては十分に適用しうるものである。

\section{3 反応係数 $\beta$ の導出}

\section{(a) 1 次可逆反応を伴う反応吸収}

アンモニア水溶液に対する $\mathrm{H}_{2} \mathrm{~S}, \mathrm{HCN}$ の吸収は, 次の解離反応を経て進行する。

$$
\begin{aligned}
& \mathrm{NH}_{3}+\mathrm{H}_{2} \mathrm{O} \rightleftarrows \mathrm{NH}_{4}^{+}+\mathrm{OH}^{-} \\
& \mathrm{H}_{2} \mathrm{~S} \rightleftarrows \mathrm{H}^{+}+\mathrm{HS}^{-} \\
& \mathrm{HCN} \rightleftarrows \mathrm{H}^{+}+\mathrm{CN}^{-}
\end{aligned}
$$

$\mathrm{H}_{2} \mathrm{~S}$ の場合, (4)，(5)式から

$$
\mathrm{H}_{2} \mathrm{~S}+\mathrm{NH}_{3}+\mathrm{H}_{2} \mathrm{O} \rightleftarrows\left(\mathrm{NH}_{4}\right) \mathrm{HS}+\mathrm{H}_{2} \mathrm{O}
$$

となる。これらの反応は $\mathrm{H}_{2} \mathrm{~S}, \mathrm{HCN}$ に着目して 1 次 可逆反応を仮定でき, 反応が

$$
\mathrm{A} \rightleftarrows \mathrm{E}
$$

に従っており，その反応速度が

$$
-\mathrm{dA} / \mathrm{dt}=\mathrm{dE} / \mathrm{dt}=\mathrm{k}_{1} \mathrm{~A}-\mathrm{k}_{2} \mathrm{E}
$$

で与えられる。

このような 1 次可逆反応を伴うガス吸収を Fig. 6 の境膜モデルにより解析した。境界条件を

$\mathrm{x}=0$ に扔いて $\mathrm{A}=\mathrm{A}_{\mathrm{i}}, \mathrm{dE} / \mathrm{dx}=0$

$\mathrm{x}=\mathrm{x}_{\mathrm{f}}$ において $\left.\mathrm{A}=\mathrm{A}_{\mathrm{L}}, \mathrm{E}=\mathrm{E}_{\mathrm{L}}, \mathrm{E}_{\mathrm{L}} / \mathrm{A}_{\mathrm{L}}=\mathrm{K}\right\}$ (10)

とすると, 吸収速度式として Peaceman によって導出 された次式が得られる8)

$$
\mathrm{N}_{\mathrm{A}}=\mathrm{D}_{\mathrm{A}} \frac{\left(\mathrm{A}_{\mathrm{i}}-\mathrm{A}_{\mathrm{L}}\right)}{\mathrm{x}_{\mathrm{f}}} \cdot \frac{1+\frac{\mathrm{KD}_{\mathrm{E}}}{\mathrm{D}_{\mathrm{A}}}}{1+\frac{\mathrm{KD}_{\mathrm{E}}}{\mathrm{D}_{\mathrm{A}}} \cdot \frac{\operatorname{tanhR} \cdot \mathrm{x}_{\mathrm{f}}}{\mathrm{R} \cdot \mathrm{x}_{\mathrm{f}}}}
$$

ただし， $\mathrm{R}=\sqrt{\mathrm{k}_{1} / \mathrm{D}_{\mathrm{A}}+\mathrm{k}_{2} / \mathrm{D}_{\mathrm{E}}}$

反応を伴う場合の液測物質移動係数 $\mathrm{k}_{\mathrm{L}}$ を物理吸収 のときの吸収速度式と同様に

$$
\mathrm{N}_{\mathrm{A}}=\mathrm{k}_{\mathrm{L}}\left(\mathrm{A}_{\mathrm{i}}-\mathrm{A}_{\mathrm{L}}\right)
$$

と与えた場合, 物理吸収における物質移動係数 $\mathrm{k}_{\mathrm{L}}{ }^{*}$ は

$$
\mathrm{k}_{\mathrm{L}}^{*}=\mathrm{D}_{\mathrm{A}} / \mathrm{x}_{\mathrm{f}}
$$

であり，かつ $\beta=\mathrm{k}_{\mathrm{L}} / \mathrm{k}_{\mathrm{L}}{ }^{*}$ と定義されるから，(11), (13)，(14)式から $\beta$ は次式のように導出される。

$$
\beta=\frac{1+\frac{\mathrm{KD}_{\mathrm{E}}}{\mathrm{D}_{\mathrm{A}}}}{1+\frac{\mathrm{D}_{\mathrm{E}}}{\mathrm{D}_{\mathrm{A}}} \cdot \frac{\tanh \gamma \sqrt{1+\mathrm{D}_{\mathrm{A}} / \mathrm{KD}_{\mathrm{E}}}}{\gamma \sqrt{1+\mathrm{D}_{\mathrm{A}} / \mathrm{KD}_{\mathrm{E}}}}}
$$

ただし, $\gamma=\sqrt{\mathrm{k}_{1} \mathrm{D}_{\mathrm{A}}} \cdot \mathrm{x}_{\mathrm{f}}=\sqrt{\mathrm{k}_{1} \mathrm{D}_{\mathrm{A}}} / \mathrm{k}_{\mathrm{L}}$ *

(15)式において $\gamma=0$ ，または $\mathrm{K}=0$ とすると

$$
\beta=1
$$

となって物理吸収の場合に相当し， $\gamma=\propto$ とすれば

$$
\beta=1+\mathrm{KD}_{\mathrm{E}} / \mathrm{D}_{\mathrm{A}}
$$

となり, $\mathrm{A} \rightleftarrows \mathrm{E}$ の反応が瞬間的に完結し, 瞬間可逆 反応の場合に対応する。

\section{(b) $\mathrm{H}_{2} \mathrm{~S}, \mathrm{HCN}$ の反応係数 $\beta$}

$\mathrm{H}_{2} \mathrm{~S}, \mathrm{HCN}$ の $\mathrm{NH}_{3}$ 水への反応吸収は 1 次可逆反応 を想定でき, Fig. 6 のモデルにおいて未反応溶解ガ ス $\mathrm{A}_{\mathrm{L}}$ と解離生成物 $\mathrm{E}_{\mathrm{L}}$ とが平衡状態にある場合であ $\eta$, 反応係数 $\beta$ は(18)式より

$$
\beta=1+\mathrm{KD}_{\mathrm{E}} / \mathrm{D}_{\mathrm{A}}=1+\mathrm{E}_{\mathrm{L}} \mathrm{D}_{\mathrm{E}} / \mathrm{A}_{\mathrm{L}} \mathrm{D}_{\mathrm{A}}
$$

となる。ここで $\mathrm{D}_{\mathrm{A}}$ は $\mathrm{H}_{2} \mathrm{~S}$ ないし $\mathrm{HCN}$ の拡散係数, $\mathrm{D}_{\mathrm{E}}$ は $\mathrm{HS}^{-}$ないし $\mathrm{CN}^{-}$拡散係数である。これらの拡散 係数は液相の場合一般にWilke の式が適用され，こ こにおいて拡散係数 D と沸点分子容 $\mathrm{V}$ との間に次の 関係がある。

$$
\mathrm{D}=\mathrm{k} / \mathrm{V}^{0.6}
$$

それぞれの沸点分子容から $\mathrm{D}_{\mathrm{E}} / \mathrm{D}_{\mathrm{A}}$ を算出すると， $\mathrm{H}_{2} \mathrm{~S}$ の場合

$\mathrm{D}_{\mathrm{E}} / \mathrm{D}_{\mathrm{A}}=\mathrm{D}_{\mathrm{HS}^{-}} / \mathrm{D}_{\mathrm{H} 2 \mathrm{~S}}=(32.9 / 29.2)^{0.6}=1.074$ $\mathrm{HCN}$ の場合

$\mathrm{D}_{\mathrm{E}} / \mathrm{D}_{\mathrm{A}}=\mathrm{D}_{\mathrm{CN}^{-}} / \mathrm{D}_{\mathrm{HCN}}=(33.3 / 29.6)^{0.6}=1.073$ となり，いずれの場合も $\mathrm{D}_{\mathrm{E}} / \mathrm{D}_{\mathrm{A}} \fallingdotseq 1$ であるから 近似解として

$$
\beta=1+\mathrm{E}_{\mathrm{L}} / \mathrm{A}_{\mathrm{L}}=1+\mathrm{C}_{\mathrm{E}_{\mathrm{L}}} / \mathrm{C}_{\mathrm{A}_{\mathrm{L}}}
$$

と表すことができる。

ここで気相 $\mathrm{HCN}\left(\mathrm{G}_{\mathrm{A}}\right)$ の溶解反応に着目すると, 気 液境界面の $\mathrm{HCN}\left(\mathrm{C}_{\mathrm{A}_{\mathrm{i}}}\right)$ は一部が解離して

$\mathrm{CN}^{-}\left(\mathrm{C}_{\mathrm{E}_{\mathrm{i}}}\right)$ となり, 液相で $\mathrm{NH}_{4}{ }^{+}$と反応して

$\mathrm{NH}_{4} \mathrm{CN}\left(\mathrm{C}_{\mathrm{E}_{\mathrm{L}}}\right)$ を生成し, 残部は未反応 $\mathrm{HCN}\left(\mathrm{C}_{\mathrm{A}_{\mathrm{L}}}\right)$ と なるためバランス上は次式で表せる。

$$
\mathrm{C}_{\mathrm{A}_{\mathrm{i}}}=\mathrm{C}_{\mathrm{E}_{\mathrm{L}}}+\mathrm{C}_{\mathrm{A}_{\mathrm{L}}}
$$

$\mathrm{G}_{\mathrm{A}}$ と平衡にある液本体の $\mathrm{HCN}$ を $\mathrm{C}_{\mathrm{A}_{\mathrm{L}}}{ }^{*}$ とすると $\mathrm{C}_{\mathrm{A}_{\mathrm{L}}}{ }^{*}$ は $\mathrm{C}_{\mathrm{A}_{\mathrm{i}}}$ で近似されるため, 化学吸収による溶解 


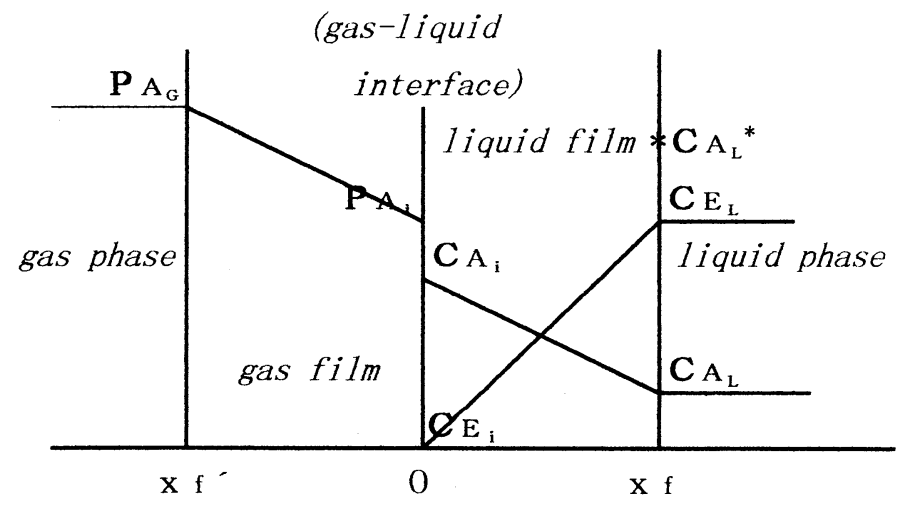

Fig. 6 Film theory model of gas absorption with first-order reversible reaction

$\mathrm{P}_{\mathrm{AG}}=$ vapor pressure of solute gas in gas phase, $\mathrm{P}_{\mathrm{Ai}}=$ vapor pressure of solute gas at gas interface, $\mathrm{C}_{\mathrm{Ai}}=$ concentration of disolving gas at liquid interface, $\mathrm{C}_{\mathrm{A}_{\mathrm{L}}}=$ concentration of solute gas in liquid phase, $\mathrm{C}_{\mathrm{Ei}}$ $=$ concentration of species $\mathrm{E}$ at liquid interface, $\mathrm{C}_{\mathrm{E}_{\mathrm{L}}}=$ concentration of species $\mathrm{E}$ in liquid phase, $\mathrm{C}_{\mathrm{A}}{ }^{*}=$ concentration of solute gas in liquid phase in a state of equilibrium to $\mathrm{P}_{\mathrm{AG}_{\mathrm{G}}}$

平衡係数は

$$
\mathrm{H}=\mathrm{G}_{\mathrm{A}} / \mathrm{C}_{\mathrm{A}_{\mathrm{L}}}^{*}=\mathrm{G}_{\mathrm{A}} / \mathrm{C}_{\mathrm{A}_{\mathrm{i}}}
$$

となり, 物理吸収の溶解平衡係数が

$$
\mathrm{H}^{*}=\mathrm{G}_{\mathrm{A}} / \mathrm{C}_{\mathrm{A}_{\mathrm{L}}}
$$

となることから，(20)，(21)，(22) および(23)式から $\beta$ を算 出すると

$$
\begin{aligned}
& \beta=1+\frac{C_{E_{L}}}{C_{A_{L}}}=\frac{C_{A_{L}}+C_{E_{L}}}{C_{A_{L}}} \\
& =\left(G_{A} / H\right) /\left(G_{A} / H^{*}\right)=\frac{H^{*}}{H}
\end{aligned}
$$

となり， $\beta$ を $\mathrm{H}^{*}$ と $\mathrm{H}$ の比として求めることができる。

\section{(c) $\mathrm{CO}_{2}$ の反応係数 $\beta$}

水溶液中での $\mathrm{CO}_{2}$ と $\mathrm{NH}_{3}$ の反応については多くの 研究 ${ }^{9)}{ }^{10)}$ が行われており, 正田ら ${ }^{4)}$ はカルバミン酸の 生成反応

$$
\mathrm{CO}_{2}+\mathrm{NH}_{3} \rightleftarrows \mathrm{H}^{+}+\mathrm{NH}_{2} \mathrm{COO}^{-}
$$

と,この反応に引き続いて起こる $\mathrm{H}^{+}$の中和反応

$$
\mathrm{H}^{+}+\mathrm{NH}_{3} \rightleftarrows \mathrm{NH}_{4}^{+}
$$

の両反応加構成される総括反応

$$
\mathrm{CO}_{2}+2 \mathrm{NH}_{3} \rightleftarrows \mathrm{NH}_{4}^{+}+\mathrm{NH}_{2} \mathrm{COO}^{-}
$$

を主反応とし, 炭酸化度の低い $\mathrm{NH}_{3}$ 水溶液中への $\mathrm{CO}_{2}$ の吸収は, $\mathrm{CO}_{2}$ に関して 1 次, $\mathrm{NH}_{3}$ に関して 1 次の反応速度を持つ不可逆 2 次反応として取り扱い, 浸透説によって解析している。

本研究ではV Van Krevelen らの提案している反応モ デル

$$
\mathrm{NH}_{3}+\mathrm{H}_{2} \mathrm{O} \rightleftarrows \mathrm{NH}_{4}^{+}+\mathrm{OH}^{-}
$$

と,この反応に引き続いて起こる

$$
\begin{aligned}
& \mathrm{CO}_{2}+\mathrm{OH}^{-} \rightleftarrows \mathrm{HCO}_{3}^{-} \\
& \mathrm{NH}_{4}{ }^{+}+\mathrm{HCO}_{3}{ }^{-} \rightleftarrows\left(\mathrm{NH}_{4}\right) \mathrm{HCO}_{3}
\end{aligned}
$$

の反応から構成される次の総括反応

$$
\mathrm{NH}_{3}+\mathrm{H}_{2} \mathrm{O}+\mathrm{CO}_{2} \rightleftarrows\left(\mathrm{NH}_{4}\right) \mathrm{HCO}_{3}
$$

を主反応と位置づけ, 吸収モデルとしては $\mathrm{CO}_{2}$ に関 して 1 次, $\mathrm{OH}^{-}$に関して 1 次の反応速度を持つ不可 逆 2 次反応として取り扱い, 境膜説によって解析した。 さらにこれに引き続く反応として,

$$
\begin{aligned}
& \mathrm{NH}_{3}+\mathrm{HCO}_{3}{ }^{-} \rightleftarrows \mathrm{NH}_{2} \mathrm{COO}^{-}+\mathrm{H}_{2} \mathrm{O} \\
& \mathrm{NH}_{3}+\mathrm{HCO}_{3}{ }^{-} \rightleftarrows \mathrm{NH}^{+}+\mathrm{CO}_{3}{ }^{--}
\end{aligned}
$$

によるカルバミン酸および炭酸の生成反応があるが, (32)，(33) 式に比して (28) 式の解離反応を内包する総括反 応 (31) 式は反応速度が遅く律速と考えられる。

不可逆 2 次反応モデルは Fig. 7 に示したもので, 反応係数 $\beta$ は八田 ${ }^{11)}$ の境膜説

$$
\beta=1+\frac{\mathrm{D}_{\mathrm{B}}}{\mathrm{D}_{\mathrm{A}}} \cdot \frac{\mathrm{C}_{\mathrm{B}_{\mathrm{L}}}}{\nu \mathrm{C}_{\mathrm{A}_{\mathrm{i}}}}
$$

により解析した。ここにンは化学量論数である。(28), (29), (30) 式から, $\mathrm{C}_{\mathrm{A}_{\mathrm{i}}}$ は一部が $\left(\mathrm{NH}_{4}\right) \mathrm{HCO}_{3}$ を生成して $\mathrm{C}_{\mathrm{E}_{\mathrm{L}}}$ となり, 残部は不溶解 $\mathrm{CO}_{2}$ として $\mathrm{CA}_{\mathrm{L}}$ となる。 すなわち,

$$
\mathrm{C}_{\mathrm{A}_{\mathrm{i}}}=\mathrm{C}_{\mathrm{E}_{\mathrm{L}}}+\mathrm{C}_{\mathrm{A}_{\mathrm{L}}}
$$

$\mathrm{C}_{\mathrm{B}_{\mathrm{L}}}$ は $\mathrm{OH}^{-}$であり, 反応を通じて当モルの $\left(\mathrm{NH}_{4}\right)$ $\mathrm{HCO}_{3}$ を生成して $\mathrm{C}_{\mathrm{E}_{\mathrm{L}}}$ となる。したがって,

$$
\mathrm{C}_{\mathrm{B}_{\mathrm{L}}}=\mathrm{C}_{\mathrm{E}_{\mathrm{L}}}
$$

本吸収モデルで $\mathrm{G}_{\mathrm{A}}$ と平衡な未反応溶質ガスを $\mathrm{C}_{\mathrm{A}_{\mathrm{L}}}{ }^{*}$ とし, その近似式を 


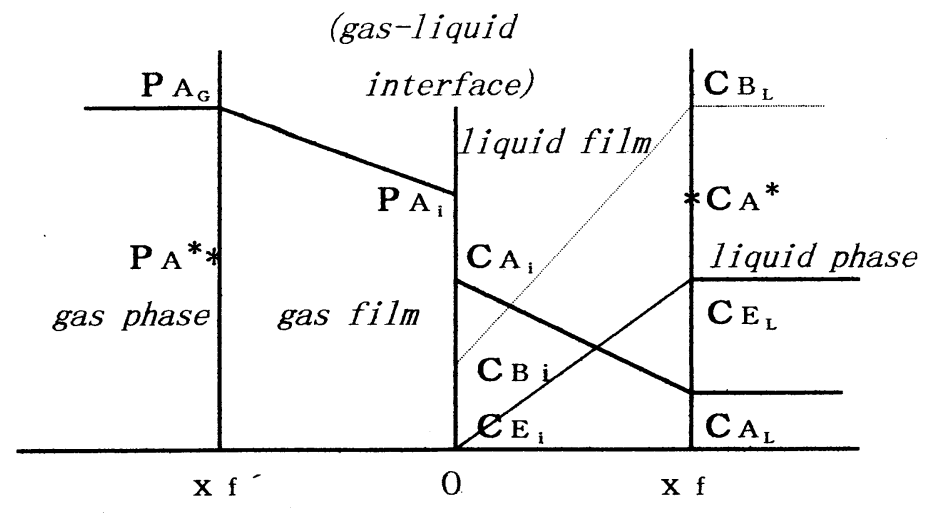

Fig. 7 Film theory model of gas absorption with irreversible second-order reaction

$\mathrm{P}_{\mathrm{A}_{\mathrm{G}}}=$ vapor pressure of solute gas in gas phase, $\mathrm{P}_{\mathrm{Ai}}=$ vapor pressure of solute gas at gas interface, $\mathrm{C}_{\mathrm{Ai}}=$ concentration of disolving gas at liquid interface, $\mathrm{C}_{\mathrm{A}_{\mathrm{L}}}=$ concentration of solute gas in liquid phase, $C_{B i}=$ concentration of dissolved regent at liquid interface, $C_{B_{L}}=$ initial concentration of dissolved regent in liquid phase, $\mathrm{C}_{\mathrm{Ei}}=$ concentration of species $\mathrm{E}$ at liquid interface, $\mathrm{C}_{\mathrm{E}_{\mathrm{L}}}=$ concentration of species $\mathrm{E}$ in liquid phase, $\mathrm{P}_{\mathrm{A}}{ }^{*}=$ vapor pressure in a state of equilibrium to $\mathrm{C}_{\mathrm{A}_{\mathrm{L}}}, \mathrm{C}_{\mathrm{A}}{ }^{*}=$ concentration of solute gas in liquid phase in a state of equilibrium to $P_{A_{G}}$

$$
\mathrm{C}_{\mathrm{A}_{\mathrm{L}}}^{*}=\mathrm{C}_{\mathrm{A}_{\mathrm{L}}}+\mathrm{C}_{\mathrm{E}_{\mathrm{L}}}
$$

とすると, 化学吸収による溶解平衡係数 $\mathrm{H}$ は

$$
\mathrm{H}=\mathrm{G}_{\mathrm{A}} / \mathrm{C}_{\mathrm{A}_{\mathrm{L}}} *=\mathrm{G}_{\mathrm{A}} /\left(\mathrm{C}_{\mathrm{A}_{\mathrm{L}}}+\mathrm{C}_{\mathrm{E}_{\mathrm{L}}}\right)
$$

物理吸収による溶解平衡係数は

$$
\mathrm{H}^{*}=\mathrm{G}_{\mathrm{A}} / \mathrm{C}_{\mathrm{A}_{\mathrm{L}}}
$$

拡散係数については溶質ガス $\mathrm{CO}_{2}$ ，および反応溶質 $\mathrm{OH}^{-}$にWilke の式を適用し,

$\mathrm{D}_{\mathrm{B}} / \mathrm{D}_{\mathrm{A}}=(34.0 / 11.1)^{0.6}=2.0$ を得るので, $\nu=$ 1 とすると (34)，(35)，(36)，(37)，(38)，(39) 式より

$$
\begin{aligned}
\beta & =1+\frac{\mathrm{D}_{\mathrm{B}}}{\mathrm{D}_{\mathrm{A}}} \cdot \frac{\mathrm{C}_{\mathrm{E}_{\mathrm{L}}}}{\mathrm{C}_{\mathrm{A}_{\mathrm{L}}} *} \\
& =1+2.0 \frac{\mathrm{C}_{\mathrm{E}_{\mathrm{L}}}}{\mathrm{C}_{\mathrm{E}_{\mathrm{L}}}+\mathrm{C}_{\mathrm{A}_{\mathrm{L}}}}=1+2.0\left(1-\frac{\mathrm{H}}{\mathrm{H}^{*}}\right) \\
& =3-2.0 \frac{\mathrm{H}}{\mathrm{H}^{*}}
\end{aligned}
$$

となり, $\mathrm{NH}_{3}$ 水溶液による $\mathrm{CO}_{2}$ の反応吸収の場合も 反応係数 $\beta$ は $\mathrm{H}$ と $\mathrm{H}^{*}$ の比として求められる。ただ し $\mathrm{CO}_{2}$ の場合には $1 \leqq \beta<3$ となる。

\section{4. 考 察}

本研究ではアンモニア水溶液の希薄領域における $\mathrm{HCN}, \mathrm{H}_{2} \mathrm{~S}$ の反応吸収が可逆 1 次反応モデルとして, また $\mathrm{CO}_{2}$ が不可逆 2 次反応モデルとして近似的に示 せることに言及し, 反応係数 $\beta$ を溶解平衡係数 $\mathrm{H}$ と ヘンリー定数 $\mathrm{H}^{*}$ の比で表せることを示した。

Fig. 8 にはアンモニア水溶液中の HCN の反応係数 $\beta$ を示したが, $\mathrm{NH}_{3}$ 濃度との強い相関はあるが, 10 ～50ㄷの領域では温度の影響をほとんど受けておらず， ヘンリー定数が大きく水に対する溶解度の小さい $\mathrm{H}_{2} \mathrm{~S}$ や $\mathrm{CO}_{2}$ とは明らかに異なる性状を示している。

HCN は水に極めて溶解しやすい性質を有するが,

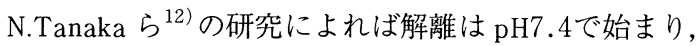
pH9.4で50\%，pH11.4で99\%であり，十分に解離す るには比較的高いアルカリ度が必要なためと考えられ る。物理吸収との差異を示す $\beta$ は10 200で極めて大 きく, 反応吸収性が高いことを示している。

$\mathrm{H}_{2} \mathrm{~S}$ は純水への溶解度は極めて低いが $\mathrm{pH} 4$ 以上で 解離する性質があり, アンモニア水溶液中では $\mathrm{NH}_{3}$ との比 $\mathrm{R}\left(\mathrm{L}-\mathrm{H}_{2} \mathrm{~S} / \mathrm{L}-\mathrm{NH}_{3}\right)$ によって反応吸収性が大き く変動することが判った。

Fig. 9, Fig.10にそれぞれ $\mathrm{R}=0.2, \quad \mathrm{R}=0.80 \beta$ を示したが, 前者の場合 $1000<\beta<3000$, 後者では35 $<\beta<200$ となっており, 物理吸収に比してその吸収 性が大幅に高まっている。このことは希薄アンモニア 水であっても $\mathrm{R}$ を低く設定することにより高い脱硫 率が得られることを示唆している。

$\mathrm{CO}_{2}$ については(40)式により $\beta$ の近似解が得られるが, 常に $1 \leqq \beta<3$ となることを示している。検討対象範 囲の中で最も $\mathrm{H}^{*} / \mathrm{H}$ の小さいケースとして Fig.11 を示したが，この場合でも $200<\mathrm{H}^{*} / \mathrm{H}<2000 て ゙ あ り ，$ $\mathrm{H} / \mathrm{H}^{*}$ は常に0.005以下となるため検討対象範囲で

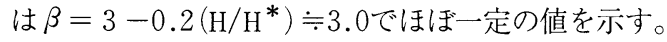




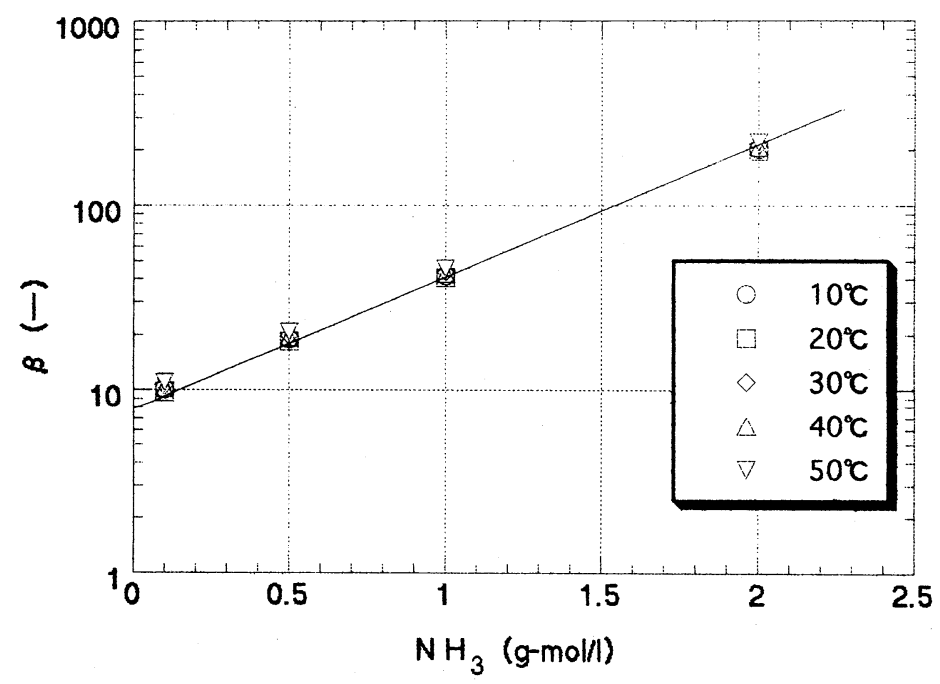

Fig. 8 Reaction factor $\beta$ of $\mathrm{HCN}$ in ammonia water

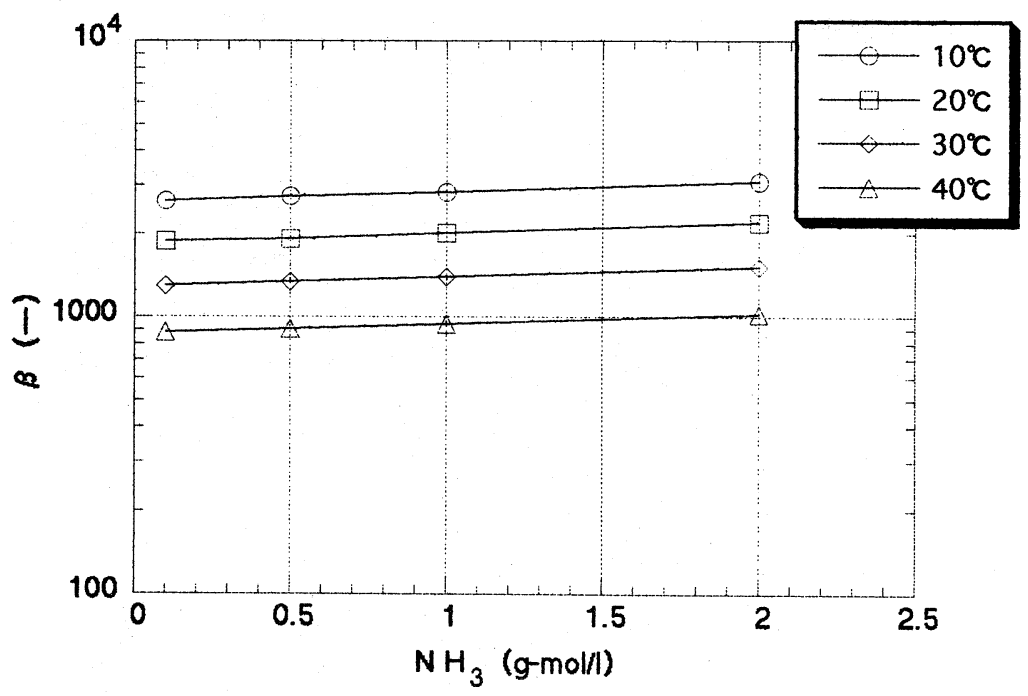

Fig. 9 Reaction factor $\beta$ of $\mathrm{H}_{2} \mathrm{~S}$ in ammonia water $(\mathrm{R}=0.2) \quad \mathrm{R}=\mathrm{L}-\mathrm{H}_{2} \mathrm{~S} / \mathrm{L}-\mathrm{NH}_{3}$

$\mathrm{CO}_{2}$ が過大の場合や反応温度が高い時には $\beta$ は限り なく 1 に近づき，物理吸収の挙動を示すことになる。

\section{5. 結 言}

アンモニア水溶液に対する $\mathrm{HCN}, \mathrm{H}_{2} \mathrm{~S}$ および $\mathrm{CO}_{2}$ の溶解平衡係数 $\mathrm{H}$ を実測ないしは文献値から導出し, さらにこの值とヘンリー定数 $\mathrm{H}^{*}$ との関係から反応係 数 $\beta$ を近似解として算出し, 以下の結果を得た。

(1) $\mathrm{HCN}-\mathrm{NH}_{3}-\mathrm{H}_{2} \mathrm{O}$ 系の平衡実験を行い, $\mathrm{HCN}$ の溶 解平衡係数 $\mathrm{H}$ を導出した。
(2) $\mathrm{H}_{2} \mathrm{~S}-\mathrm{NH}_{3}-\mathrm{H}_{2} \mathrm{O}$ 系，および $\mathrm{CO}_{2}-\mathrm{NH}_{3}-\mathrm{H}_{2} \mathrm{O}$ 系に関 しては Van Krevelen らの平衡実験デー夕を解析し, 溶解平衡係数 $\mathrm{H}$ を算出した。

(3) 反応係数 $\beta$ の導出に際し, $\mathrm{HCN}, \mathrm{H}_{2} \mathrm{~S}$ に対しては 可逆 1 次反応モデルを適用し, 近似解として $\beta=\mathrm{H}^{*}$ $/ \mathrm{H}$ で表現でき, $\mathrm{CO}_{2}$ に対しては不可逆 2 次反応モ デルを適用し，近似解として $\beta=3-2.0\left(\mathrm{H} / \mathrm{H}^{*}\right)$ で表現できることを導出した。

本研究では引き続き希薄アンモニア水による COG の精製基礎実験およびパイロットプラント実験を計画 


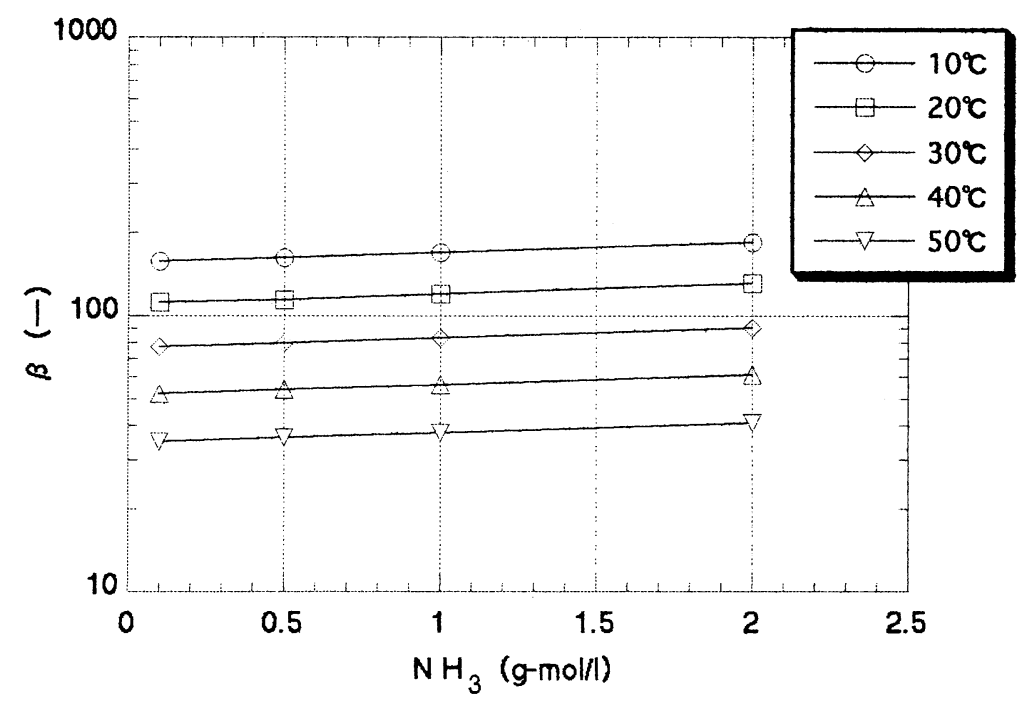

Fig.10 Reaction factor $\beta$ of $\mathrm{H}_{2} \mathrm{~S}$ in ammonia water $(\mathrm{R}=0.8) \quad \mathrm{R}=\mathrm{L}-\mathrm{H}_{2} \mathrm{~S} / \mathrm{L}-\mathrm{NH}_{3}$

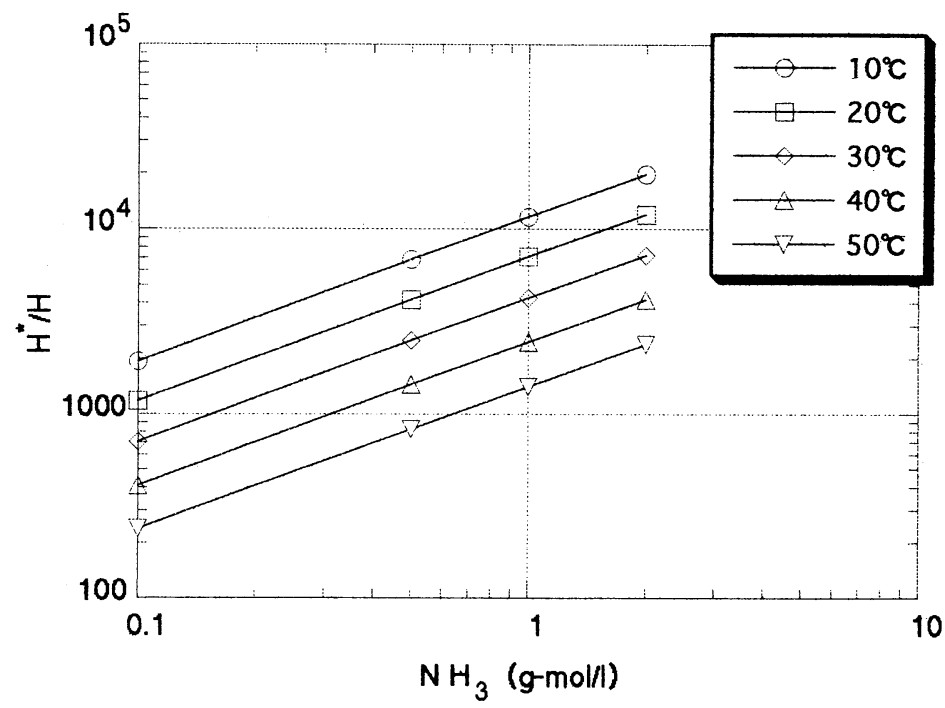

Fig.11 $\left(\mathrm{H}^{*} / \mathrm{H}\right)$ of $\mathrm{CO}_{2}$ in ammonia water $(\mathrm{R}=0.4) \quad \mathrm{R}=\mathrm{L}-\mathrm{CO}_{2} / \mathrm{L}-\mathrm{NH}_{3}$

\begin{tabular}{|c|c|c|c|c|}
\hline しており，充填塔吸収言 & 匕解析一谪 & $\mathrm{G}_{\mathrm{A}}$ & 気相中被吸収物質濃度 & {$\left[\mathrm{kg}-\mathrm{mol} / \mathrm{m}^{3}\right]$} \\
\hline 予定である。 & & & 溶解平衡係数 & {$\left[\mathrm{g}-\mathrm{mol} / \mathrm{m}^{3} / \mathrm{g}-\mathrm{mol} / \mathrm{l}\right]$} \\
\hline & & $\mathrm{H}^{*}$ & ヘンリー定数 & {$\left[\mathrm{g}-\mathrm{mol} / \mathrm{m}^{3} / \mathrm{g}-\mathrm{mol} / \mathrm{l}\right]$} \\
\hline [使用記号] & & $\mathrm{K}$ & 平衡定数 & {$[-]$} \\
\hline 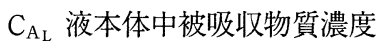 & {$\left[\mathrm{kg}-\mathrm{mol} / \mathrm{m}^{3}\right]$} & $\mathrm{k}_{1}$ & 反応速度定数 & {$[1 / \mathrm{h}]$} \\
\hline $\mathrm{C}_{\mathrm{A}_{\mathrm{i}}}$ 気液界面被吸収物質濃度 & {$\left[\mathrm{kg}-\mathrm{mol} / \mathrm{m}^{3}\right]$} & $\mathrm{N}_{\mathrm{A}}$ & 被吸収物質物質移動速度 & {$\left[\mathrm{kg} / \mathrm{m}^{2} \mathrm{~h}\right]$} \\
\hline $\mathrm{C}_{\mathrm{B}_{\mathrm{L}}}$ 液本体中反応物質濃度 & {$\left[\mathrm{kg}-\mathrm{mol} / \mathrm{m}^{3}\right]$} & $\mathrm{x}_{\mathrm{f}}$ & 境膜の厚さ & {$[\mathrm{m}]$} \\
\hline $\mathrm{C}_{\mathrm{E}_{\mathrm{L}}}$ 液本体中生成物質濃度 & {$\left[\mathrm{kg}-\mathrm{mol} / \mathrm{m}^{3}\right]$} & $\beta$ & 反応係数 & {$[-]$} \\
\hline $\mathrm{D}_{\mathrm{A}}$ 被吸収物質拡散定数 & {$\left[\mathrm{m}^{2} / \mathrm{h}\right]$} & $\nu$ & 化学量論数 & {$[-]$} \\
\hline $\mathrm{D}_{\mathrm{E}}$ 生成物質拡散定数 & {$\left[\mathrm{m}^{2} / \mathrm{h}\right]$} & & & \\
\hline
\end{tabular}




\section{文 献}

1) Kohl A. L. and Riesenfeld F. C., Gas Purification, McGRAW-HILL, (1960)

2) Williams T. H., Coke \& Gas, 16, 61 (1954)

3) Van Krevelen D. W., Hoftijzer P. J. and Huntjens F. J., Rec. Trav. Chim., 68, 191 (1949)

4) 正田晴夫, 浅井悟, 化学工学, 28, 1017 (1964)

5 ）疋田晴夫, 浅井 悟, 日昔吉紀, 化学工学, 35, 1021 (1971)

6）化学便覧 基礎編 II, 日本化学会編, 丸善, 769
7 ) J. Knox, Inorganic \& Thermodynamic Chem. 126

8) Huang C. J. and Cho C. H., A. I. Ch. E. J., 11, 901 (1965)

9 ) Danckwelts P. V. and McNeil K. M., Trans. Instn. Chem. Engrs., 45, T32 (1967)

10) Pinsent B. R., Pearson W. L. and Roughton F. W., Trans. Faraday Soc., 52, 1594 (1956)

11）八田四郎次, 工業化学雑誌，35，1389 (1932)

12) Tanaka N. and Murayama T., Z. Physik Chem., 14,370 (1958)

\title{
Study on Desulfurization of Coke Oven Gas by Diluted Ammonia Water
}

\author{
Masaaki KUROKI
}

(Corporate Technical Planning Dept., Tokyo Gas Co., Ltd.)

SYNOPSIS : - Reaction factor $\beta$ is essential to analyse the performance of gas purification by means of chemical absorption. However, it is very difficult to calculate $\beta$ which is expressed by complicated functions composed of several factors; order of chemical reaction, rate constant for chemical reaction, equilibrium constant for reaction, diffusivity of solvent gas and so on.

Therefore, simple calculation method for $\beta$ was studied in this work, and approximate equations were introduced to estimate $\beta$ by means of $\mathrm{H}^{*}$ and $\mathrm{H} . \mathrm{H}^{*}$ is ordinary Henry's law constant and $\mathrm{H}$ is Henry's law constant with chemical reaction.

For $\mathrm{HCN}-\mathrm{NH}_{3}-\mathrm{H}_{2} \mathrm{O}$ system, Henry's law constant with chemical reaction was measured by dynamic method. In case of $\mathrm{H}_{2} \mathrm{~S}-\mathrm{NH}_{3}-\mathrm{H}_{2} \mathrm{O}$ and $\mathrm{CO}_{2}-\mathrm{NH}_{3}-\mathrm{H}_{2} \mathrm{O}$ systems, constants were calculated based on Van Krevelen's experimental data.

\section{Key Words}

Henry's law constant with chemical reaction, Reaction factor $\beta$, Hydrogen cyanide, Diluted ammonia water 